\title{
Improving the Ecological Performance of Miscanthus (Miscanthus $\times$ giganteus Greef et Deuter) through Intercropping with Woad (Isatis tinctoria L.) and Yellow Melilot (Melilotus officinalis L.)
}

\author{
Moritz von Cossel ${ }^{1, *}$, Yasir Iqbal ${ }^{2} \mathbb{D}$ and Iris Lewandowski ${ }^{1}$ (D) \\ 1 Department of Biobased Products and Energy Crops (340b), Institute of Crop Science, \\ University of Hohenheim, Fruwirthstr. 23, 70599 Stuttgart, Germany \\ 2 College of Bioscience and Biotechnology, Hunan Agricultural University, Changsha 410128, Hunan, China \\ * Correspondence: moritz.cossel@uni-hohenheim.de; Tel.: +49-711-459-23557
}

Received: 31 July 2019; Accepted: 3 September 2019; Published: 6 September 2019

\begin{abstract}
Miscanthus is a promising high-yielding and low-input perennial biomass crop. However, as miscanthus does not produce nectar, it provides less support for pollinators than other perennial biomass crops, such as cup plant, Virginia mallow, or wild plant mixtures. This study discusses whether miscanthus could be intercropped with flower-rich biennial wild plants to further enhance its ecological functioning. In 2017, a demonstration plot was established in southwest Germany with two miscanthus intercropping regimes: woad (WAM) and yellow melilot (YAM). Both woad and melilot reached full bloom in 2018, the second year of cultivation. The flowering period of woad started and ended earlier than that of melilot. Woad remained harvestable until spring 2019, whereas the aboveground melilot was destroyed by brown hare in autumn 2018. However, the shed seeds of melilot reemerged homogeneously in 2019. The miscanthus developed better in YAM than WAM. This was most likely due to (i) stronger competition for water, nutrients, and light in WAM and (ii) nitrogen fixation advantage in melilot. These results indicate that the ecological performance of miscanthus could be improved by intercropping with melilot. Thus, we propose to further investigate the effects of intercropping on both the productivity and quality of miscanthus biomass.
\end{abstract}

Keywords: biennial crop; bioeconomy; biodiversity; bioenergy cropping system; biomass production; diversification; legume; perennial crop; wild plant

\section{Introduction}

The supply of sustainably produced biomass is currently one of the major challenges for the developing bioeconomy in Europe [1-3]. While the demand for biomass from industrial crops is expected to further increase in the future [4], agrobiodiversity has already started to decrease at alarming rates over the past two centuries [5-7]. For this reason, farmers need to adapt their agricultural practices in order to improve ecosystem services, such as food and shelter for open-land animals and pollinators. Another requirement is that biomass production for bioenergy or bio-based materials should not compete with food crop production, e.g., through competition for land or resources [8-10]. For this purpose, there has been a research focus on industrial crops, which can provide ecosystem services and are suitable for low-input cultivation on marginal agricultural land [11,12]. Compared with external input intensive crop cultivation on good agricultural land, these enable more social-ecologically benign biomass production with (i) less negative environmental externalities [13] and (ii) less land use competition with food crop cultivation, because they can grow on marginal agricultural land, such as erosion-prone sites, contaminated sites, or sandy soil [14-16]. In addition to bioenergy crop 
rotational systems [17] and the diversification of cropping systems through intercropping [18,19], the cultivation of $\mathrm{C} 4$ perennial energy grasses has been proven to be highly effective in terms of nutrient use efficiency [20-23] and environmental benefits, such as soil erosion mitigation, soil fertility improvement, and the provision of shelter for open-land animals during autumn and winter [16,24-27].

Miscanthus (Miscanthus $\times$ giganteus (Greef et Deuter)) is a C4 perennial energy grass with the potential to grow under low-input conditions on several types of marginal agricultural land, such as sandy soil, erosion-prone sites, and contaminated sites [11,25,28-30]. It is multifunctional and can be used for a number of utilization pathways, including combustion, biogas production, isobutanol production, and bedding material [27,31-34]. If good agricultural practices are adhered to $[16,35]$, the cultivation of miscanthus can provide the opportunity to halt the land degradation process and even restore degraded land by reducing soil erosion and improving long-term soil fertility, respectively [36-39]. This is becoming ever more relevant in the face of a changing climate, e.g., an increase of temperature and precipitation patterns [40-44], because it helps maintain agroecosystem resilience $[45,46]$. This means that by maintaining or improving the resilience level, agroecosystems will be more able to cope with extreme weather events, such as heavy rain and droughts. Such extreme weather events are expected to increase in frequency and severity in the future [43-45].

Miscanthus originates from China, where it grows naturally and does not require management practices [47,48]. In Europe, however, miscanthus cultivation is still quite challenging, in particular with regard to the establishment procedure, for example, the high establishment costs and poor biomass yield during the establishment period [49]. Several options to maximize economic benefits have been explored, including intercropping with maize during the first cultivation year [49] and intercropping within forestry systems [50]. In addition to economic benefits, ecological benefits could potentially be gained by intercropping miscanthus with other crops that complement the existing cropping system, especially during the establishment period. For example, miscanthus can store carbon [51] and has positive effects on biodiversity, such as supporting earthworm communities and functioning as a habitat for open-land animals [52,53], but it does not produce nectar or pollen. This is a clear disadvantage in comparison with cup plant (Silphium perfoliatum L.) [54], Virginia mallow (Sida hermaphrodita L.) [55-57], and perennial wild plant species [58,59], all of which produce nectar and pollen and thus support pollinators more effectively. For example, Kohli et al. (1999) found that wild flowers increase the abundance of earthworms more than miscanthus does [60]. These disadvantages indicate that there are some critical missing links in the ecological performance of miscanthus that need improving, particularly facing the challenge of rapid biodiversity loss [6]. Pollinator populations have been rapidly decreasing for decades $[5,6]$ and this require as much support as possible from agricultural systems [3,61-63]. In January 2018, both cup plant and miscanthus were approved as greening measures, but since then, a rapid expansion in cultivation area in Germany has only been observed for cup plant $[64,65]$. Miscanthus has the advantage that it can be used for a number of conversion pathways such as combustions, biogas production, and bedding material $[31,66]$, whereas cup plant can so far only be used for biogas production [54,59]. If miscanthus is harvested brown in March, it provides habitat functions during the winter [31], whereas cup plant does not, because it is harvested in autumn. These comparisons lead to the question of how the ecosystem values of miscanthus could be increased. One option to enhance the overall benefits of miscanthus cultivation for pollinators could be intercropping with biennial wild plant species. Potential candidates include yellow melilot (Melilotus officinalis L.) and woad (Isatis tinctoria L.).

Yellow melilot is a biennial legume species originating from Central Europe. It grows up to $60 \mathrm{~cm}$ high in the first year and up to $2.5 \mathrm{~m}$ in the second year (Figure 1). The flowering period is from June to September, with the blossoms providing large quantities of nectar-an ideal food source for pollinators $[67,68]$. 

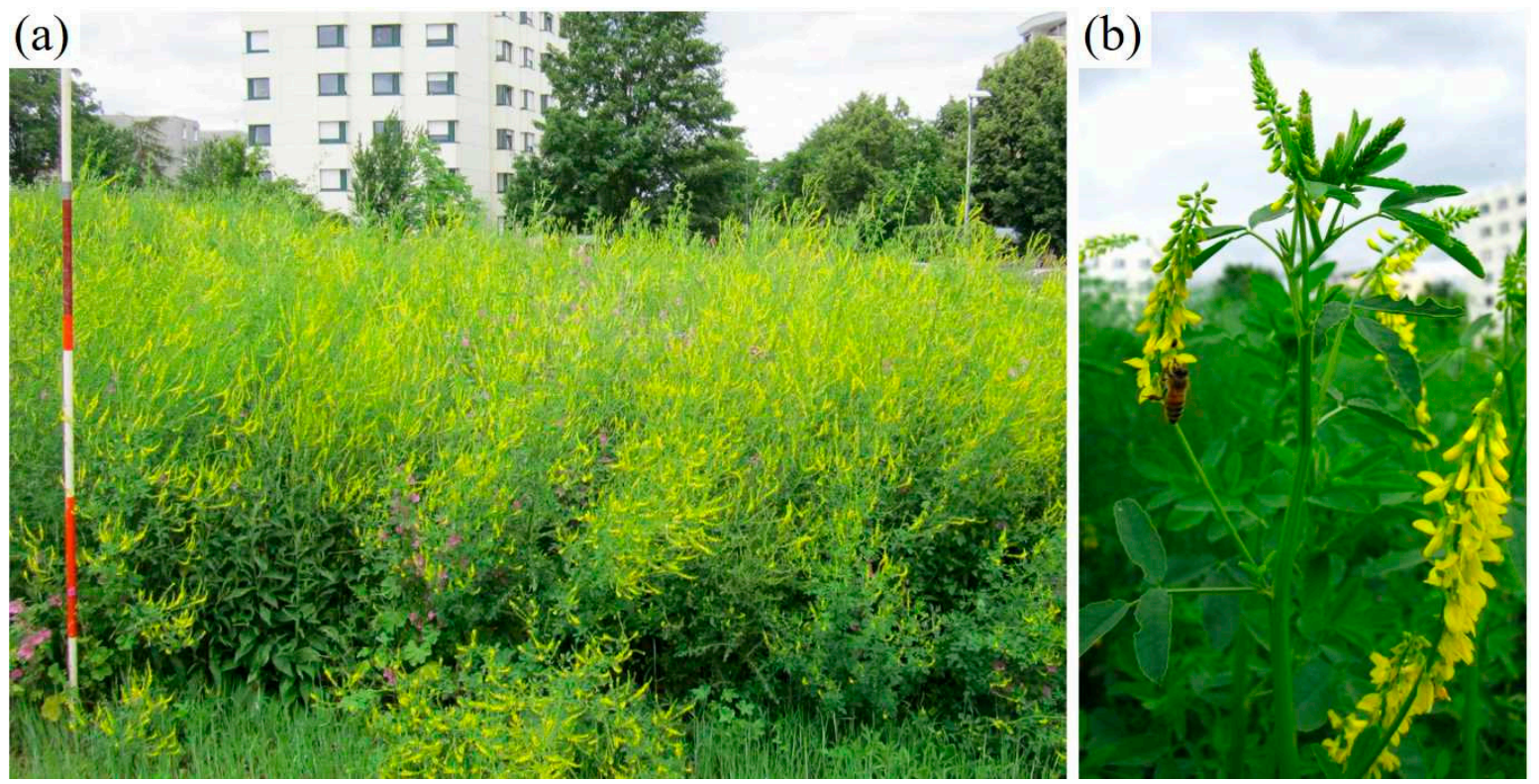

Figure 1. Yellow melilot plant height (50 cm per stick section) in the second year of cultivation (a); an inflorescence being visited by a honeybee (b) (Source: this study).

Woad is a traditional crop, which was used in the Middle Ages for textile dyeing. It develops a rosette in the first year and a main stem up to $1.5 \mathrm{~m}$ high with a yellow inflorescence in the second year (Figure 2a). Woad flowers from April to May, after which the seeds ripen and the color of the siliques changes from light green to brown (later almost black) (Figure 2b,c). The stem dries completely by autumn but remains above ground.
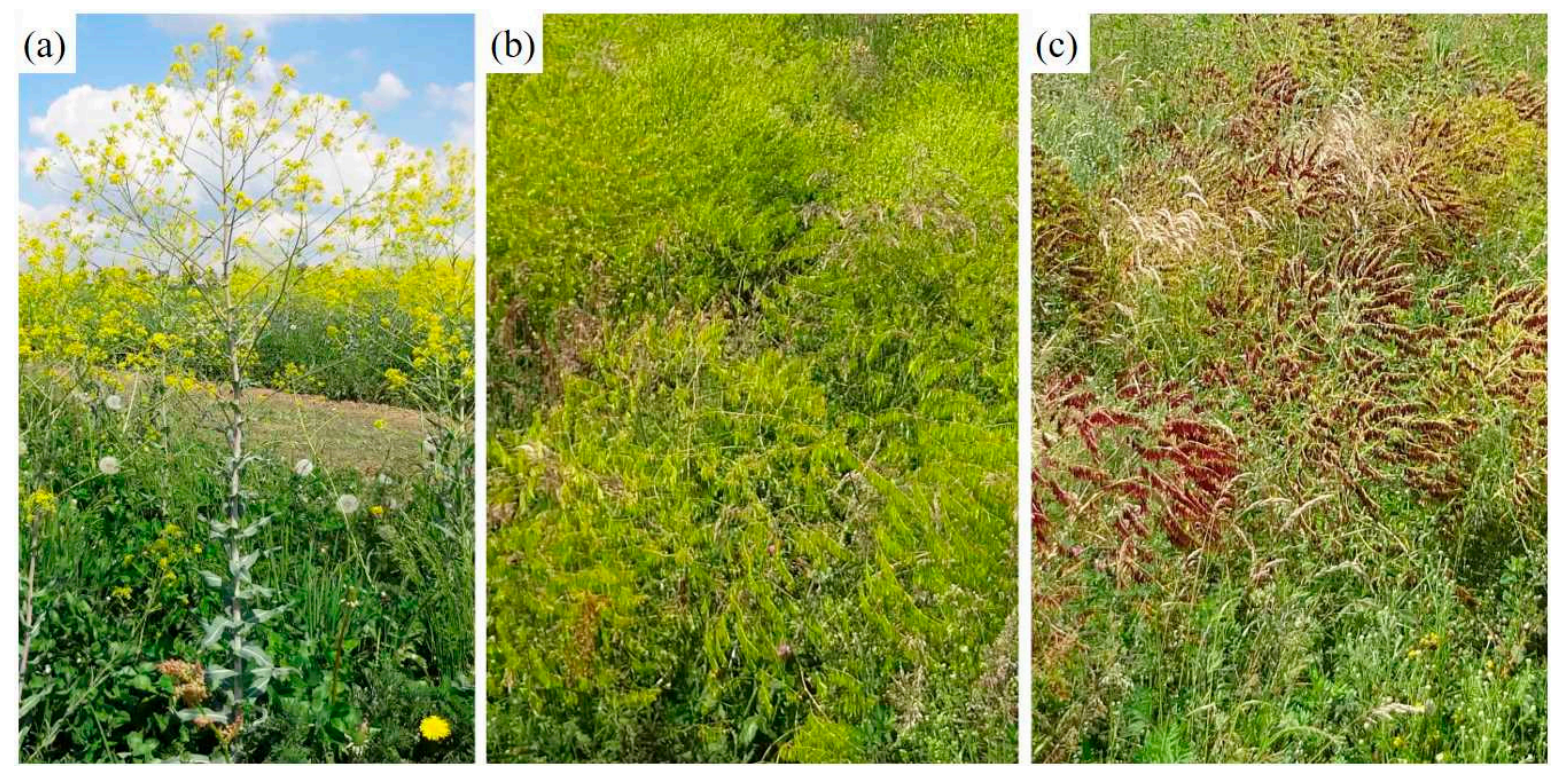

Figure 2. Woad plant morphology in the second year of cultivation (a); changing color of ripening siliques from light green (b) to dark brown (c) (Source: this study).

The aims of this study are (i) to communicate the idea of intercropping miscanthus with biennial flower-rich wild plant species woad and yellow melilot and (ii) to provide first recommendations for future investigations on intercropping miscanthus with biennial flower-rich wild plant species based on both the available literature and preliminary results from the field. 


\section{Materials and Methods}

For this study, a demo plot $(6 \mathrm{~m} \times 6 \mathrm{~m})$ (Figure 3$)$ with miscanthus (Miscanthus $\times$ giganteus Greef et Deuter) was established on 15 May 2017. The plantlets originated from rhizome propagation, and the shoots were on average $30 \mathrm{~cm}$ high at planting (Figure $4 \mathrm{a}$ ). The plot was split into two parts. One part was used for intercropping miscanthus and yellow melilot, and the other for intercropping miscanthus and woad (Figure 3). Two rows of either yellow melilot or woad were sown by hand one week after the miscanthus was planted. The sowing densities were $3.8 \mathrm{~kg} \mathrm{ha}^{-1}$ (yellow melilot) and $30 \mathrm{~kg} \mathrm{ha}^{-1}$ (woad). The miscanthus was planted at a density of 1 plant $\mathrm{m}^{-2}$.

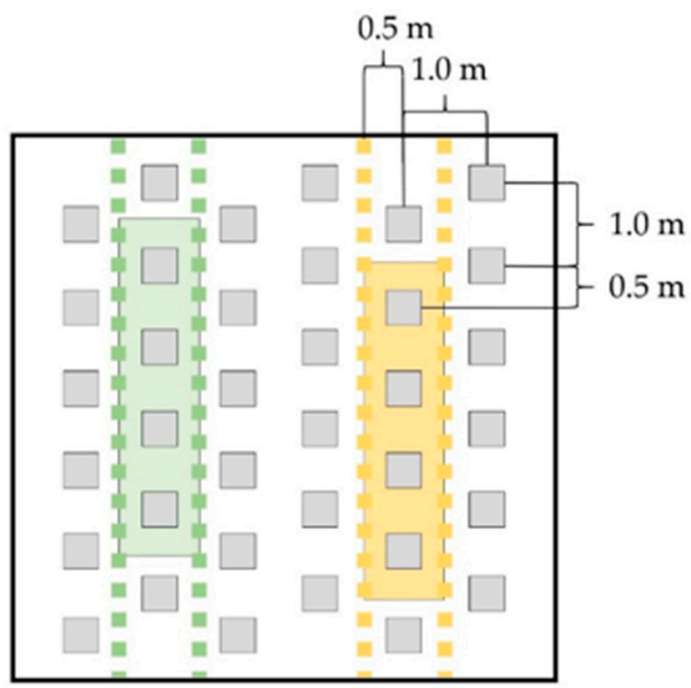

Figure 3. Schematic overview of the demonstration plot. The grey boxes represent miscanthus plantlets. The dotted lines represent undersown biennial species yellow melilot (green) and woad (yellow). The highlighted areas show sampling areas for yellow melilot (green) and woad (yellow).
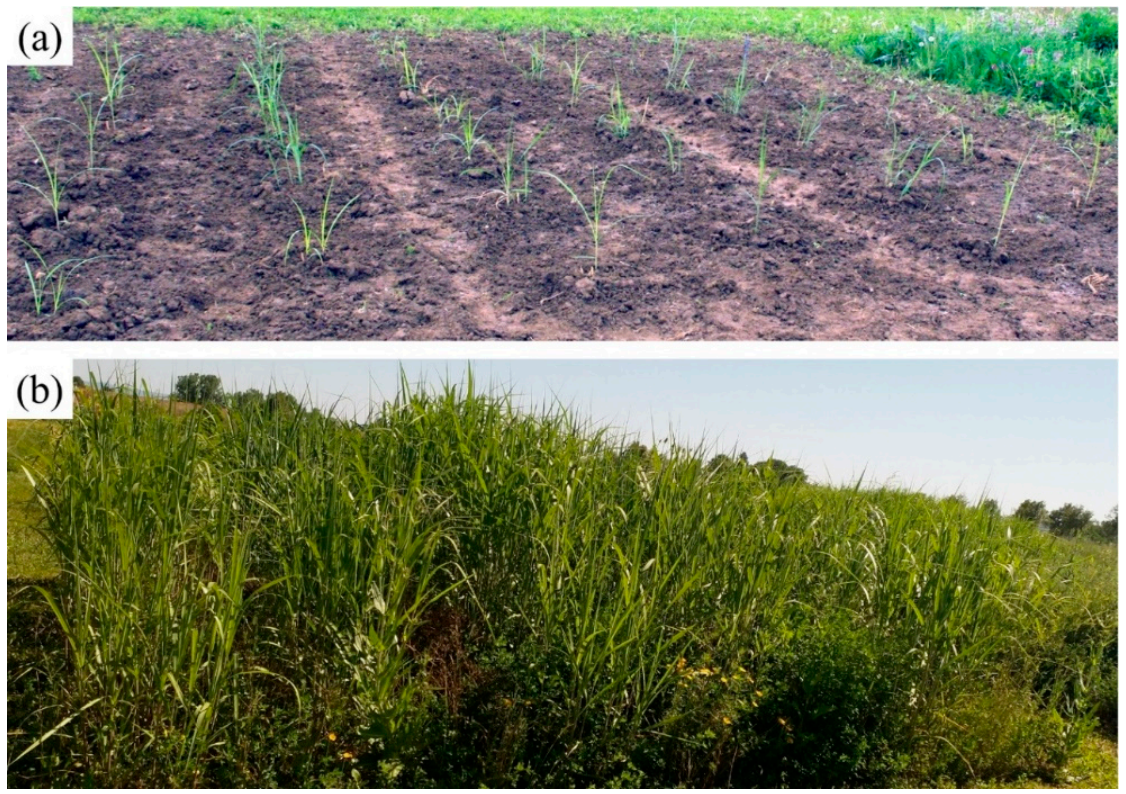

Figure 4. The demonstration plot at field trial near the University of Hohenheim in southwest Germany one day after planting (15 May 2017) (a), and during the third vegetation period (29 June 2019) (b).

Weed was removed by hand on 4 July 2017. The main weed species were creeping thistle (Cirsium arvense (L.) Scop.) and compass lettuce (Lactuca serriola L.). The aboveground biomass was evaluated in spring 2018 on a sample area of $4 \mathrm{~m}^{2}$ (Figure 3). For the evaluation, the aboveground biomass was 
harvested at a cutting height of approximately $10 \mathrm{~cm}$ using handheld garden shears. The biomass was dried at $60^{\circ} \mathrm{C}$ until constant weight to determine the dry matter content (DMC) and to calculate the dry matter yield (DMY). Furthermore, pictures of the plant stands were taken during the 2018 and 2019 vegetation periods.

\section{Results and Discussion}

Both miscanthus and the undersown biennial wild plant species yellow melilot and woad were established well (Figures 5 and 6). Miscanthus was harvested in spring 2018 (5 April 2018) and showed aboveground DMYs of 1.7 (YAM) and $2.2 \mathrm{Mg} \mathrm{ha}^{-1}$ (WAM) (Table 1), which is in line with the literature [33]. While the DMC was similar between YAM and WAM, miscanthus grew taller in YAM but the shoot density was higher in WAM (Table 1). The following subsections describe and discuss the observations of the treatments of WAM and YAM in the context of the available literature.

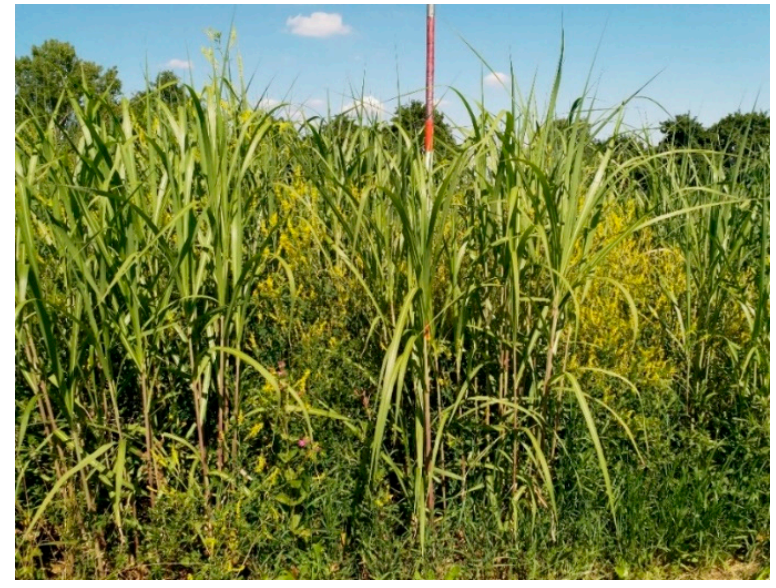

Figure 5. Plant stand of treatment yellow melilot and miscanthus (YAM) during the vegetation period in 2018. Picture taken on 8 June 2018.

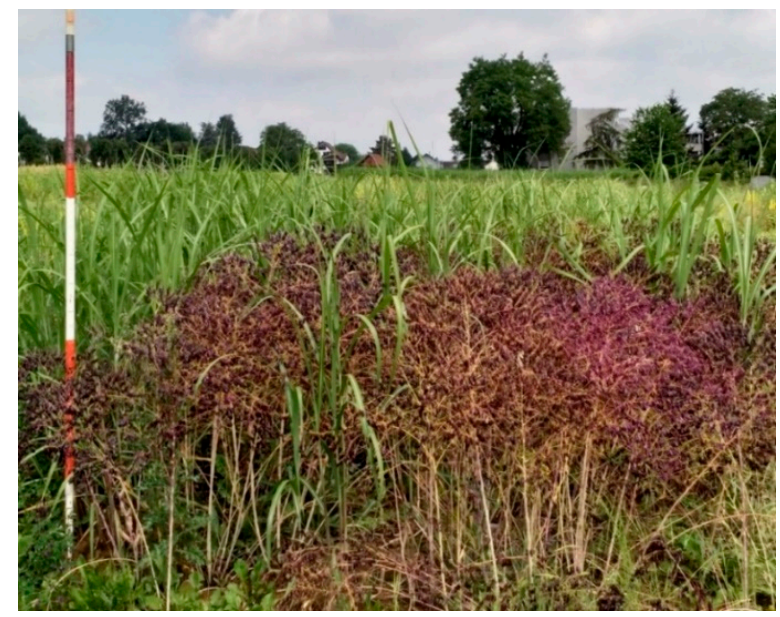

Figure 6. Plant stand of treatment woad and miscanthus (WAM) during the vegetation period in 2018. Picture taken on 8 June 2018.

Table 1. Overview of yield and morphological parameters of WAM and YAM at harvest on 5 April 2018.

\begin{tabular}{ccccc}
\hline Treatment & $\begin{array}{c}\text { Dry Matter Yield } \\
\mathbf{( M g ~ h a ~}^{-\mathbf{1}} \mathbf{)}\end{array}$ & $\begin{array}{c}\text { Dry Matter Content } \\
\text { (\% of Fresh Matter) }\end{array}$ & Number of Shoots per Plant & Plant Height (cm) \\
\hline WAM & 2.2 & 85.0 & $25.3 \pm 7.0$ & 0.91 \\
YAM & 1.7 & 87.9 & $20.8 \pm 2.9$ & 0.98 \\
\hline
\end{tabular}




\subsection{Woad and Miscanthus (WAM)}

The woad emerged well in 2017 (Figure 7) and was in good condition at the miscanthus harvest in spring 2018. Here, "good condition" means that some of the young woad plants had already established a shoot, while others had only developed a leaf rosette (Figure 7a). The woad was homogeneously distributed between and within the miscanthus rows (Figure 7). After the first harvest (spring 2018), the woad flowered during May and the first half of June. It would seem that the woad sowing density was too high and the woad rows were too close to the miscanthus for the miscanthus to cope with woad as an intercropping partner. The miscanthus plantlets in between the woad rows appeared to establish poorly compared with the miscanthus plantlets in the middle of the plot (Figure $4 \mathrm{~b}$ ), where no wild plant species were sown (Figure 3). These observations are in line with recent findings on the suitability of miscanthus established under maize [49].
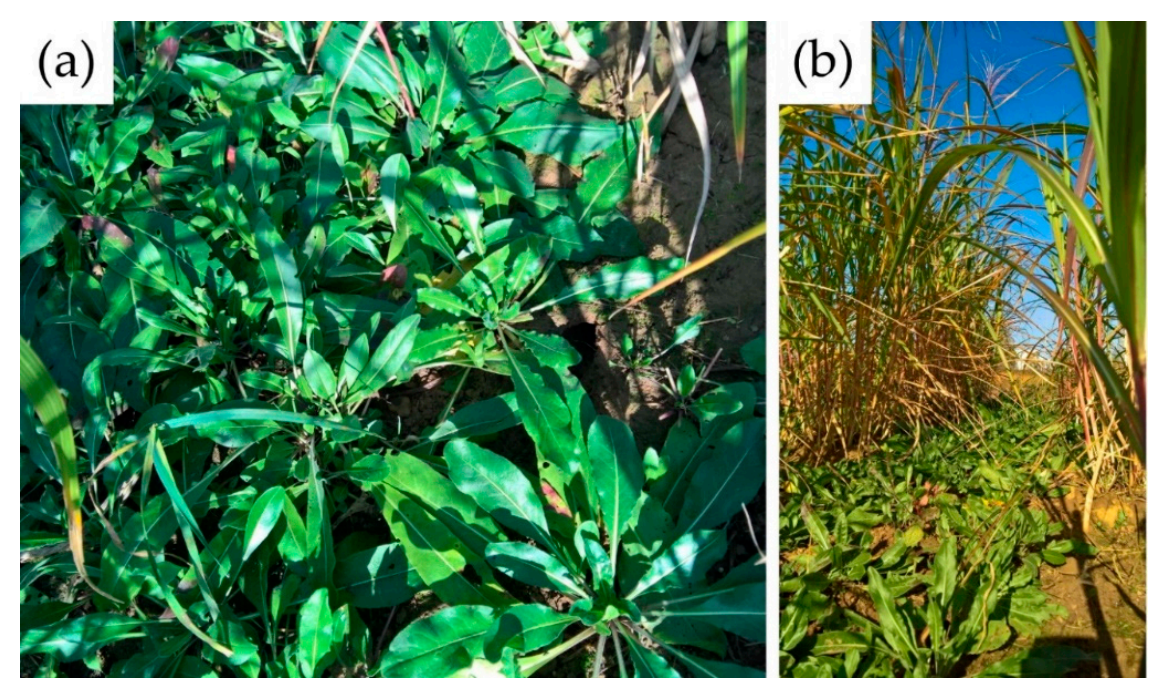

Figure 7. Morphology of woad after the vegetation period in 2017 (view from above (a), and from the side (b). The pictures were taken on 31 October 2017.

Another aspect that needs to be considered is the suitability of intercropping with woad for the subsequent cultivation years, because miscanthus has a productive lifespan of approximately 20 years [31,33]. As woad belongs to the Brassicaceae family, subsequent cultivation on the same site may increase the risk of clubroot (Plasmodiophora brassicae Woronin, 1877) infection, as is known for oilseed rape (B. napus subsp. Napus) and cauliflower (Brassica oleracea var. botrytis L.) [69,70]. This could become problematic if woad emerges successfully year after year, depending on the resistance level of the wild woad genotype against clubroot.

\subsection{Yellow Melilot and Miscanthus (YAM)}

For yellow melilot, no aboveground biomass was harvestable in spring 2018. This was because the aboveground parts were almost completely rotten, with only a few dry shoots still remaining. Most of the aboveground matter was destroyed by brown hare (Lepus europaeus Pallas, 1778) during late summer and autumn 2017, whereas the miscanthus was not damaged at all. This indicates an important additional benefit of YAM (compared with WAM) for open-land animals: the miscanthus provides shelter and the yellow melilot provides food, whereas woad does not seem to provide any nutritive value for open-land animals during winter. This is in line with the experiences of farmers who have cultivated wild plant mixtures for many years [67]. However, this aspect needs further investigation on a large scale.

During the 2018 vegetation period, the yellow melilot almost reached the same height as the miscanthus. This indicates that the yellow melilot could cope with the interaction with miscanthus and grow efficiently. In addition, successful intercropping of miscanthus with yellow melilot could 
improve the biodiversity conservation effects and landscape appearance of miscanthus compared with miscanthus cultivated alone and miscanthus intercropped with WAM. Furthermore, it is expected that yellow melilot contributes to soil fertility and provides additional nitrogen $(\mathrm{N})$ fixation, as has been reported for intercropping Virginia mallow (Sida hermaphrodita L. Rusby) and white melilot (Melilotus albus L.) [71].

\subsection{Positive Ecological Effects of Miscanthus Intercropping with Biennial Wild Plant Species}

Both woad and yellow melilot showed great potential for increasing the ecosystem values of miscanthus cropping systems, as both developed flowers providing nectar and attracting various bee and butterfly species. We assume that the woad and yellow melilot also improved the living conditions for earthworms. While miscanthus has often been proven beneficial for earthworm communities [37,38], its intercropping with wild plants, such as woad and yellow melilot may enhance this positive effect. We base this assumption on a study by Kohli et al. (1999) [60]. They found that wild flowers had a more positive effect on the abundance of earthworms than miscanthus [60].

\subsection{Economic Implications}

We assume that both intercropping systems WAM and YAM could potentially have some negative implications for the economic performance of miscanthus, possibly caused by stronger competition for both light and resources. The competition for $\mathrm{N}$ may be lower in YAM than WAM, because yellow melilot adds atmospheric $\mathrm{N}$ into the cropping system via rhizobacterial fixation. Thus, in WAM, the soil $\mathrm{N}$ balance becomes negative over time if no $\mathrm{N}$ fertilizer is applied. This means that YAM would be more suitable for low-input cultivation on marginal agricultural lands [11] than WAM. However, it should be tested in field trials on whether the long-term effect on miscanthus performance is comparable between WAM and YAM. Initial results of this study indicate that this is the case; however, yellow melilot can grow much taller (and for longer periods) than woad (Figures 1 and 2). Therefore, yellow melilot may have a much larger impact on the long-term biomass performance of miscanthus.

\subsection{Recommendations for Future Investigations}

Based on the opportunities and challenges mentioned above, several recommendations for further investigations can be derived. In general, methods of reducing the competition from woad and yellow melilot in the first and second year of miscanthus establishment need to be assessed. This competition is most relevant in the first year when the miscanthus is planted. A reduction in competition could possibly be achieved by (i) reducing the plant density of woad and yellow melilot and (ii) delaying the sowing of woad and yellow melilot within the planting year or to the second year of miscanthus establishment.

A reduction in woad or yellow melilot plant density (e.g., through wider row distances and/or lower sowing densities) is not expected to provide a long-term solution to the problem, as both species can produce large amounts of seeds, which are likely to disperse throughout the miscanthus plantation over time. In the best case, intercropping miscanthus with yellow melilot and woad could perhaps reduce weed pressure during the establishment period of miscanthus, which can last up to four years [33,49]. However, it remains unclear how long it would take for miscanthus to fully establish within these intercropping systems. This should be further investigated in field trials that also contain the treatment 'no weeding'.

By comparison, the delayed sowing of woad or yellow melilot appears to be a much more promising method of reducing their competitiveness. For example, miscanthus could be established as usual (alone) in the first year [31,33] to improve its establishment success. Then, woad or yellow melilot could be undersown in the second year immediately after the first harvest (or mulching) of miscanthus in winter. This would not have any implications for the sowing procedure, because both woad and yellow melilot can be sown on top of the soil $[58,68]$. The mulch layer of miscanthus leaves is not expected to impede the emergence of the woad or yellow melilot seeds. This assumption is based on 
observations from another field trial with wild plant mixtures [59]. The sowing procedure of woad and yellow melilot would not be a problem for intercropping with miscanthus, because it can be performed before the miscanthus emerges. In addition, woad and yellow melilot would (i) remain small in the second year of miscanthus cultivation and (ii) fully establish in the third year of miscanthus cultivation when the miscanthus is almost completely established [31,72,73]. This would allow the miscanthus a second year of low competitive pressure and increase the probability of its good establishment.

The research question to be addressed here is the long-term effect of intercropping on the miscanthus biomass yield. A subsequent question would be how yellow melilot and woad should best be managed, for instance, through an early cut or mechanical weeding in spring. In any case, it can be assumed that, from the third year onwards, woad and yellow melilot could significantly improve the ecosystem services of miscanthus cultivation through the provision of nectar and pollen for insects. This could also improve the overall sustainability of miscanthus cultivation with comparably low input. For example, sowing woad or yellow melilot in the second year of miscanthus cultivation without any seedbed preparation would reduce energy consumption considerably. For YAM, the potential substitution of synthetic $\mathrm{N}$ fertilizer through atmospheric $\mathrm{N}$ fixation would greatly depend on the proportion of yellow melilot in the plant stand. However, this aspect also needs to be investigated at the field trial scale.

Another question to be addressed is which other legume species would be suitable for intercropping with miscanthus. According to Nabel et al. (2018) [56,71], who reported on the suitability of Virginia mallow for legume-intercropping, possibilities include red clover (Trifolium pratense L.), white clover (Trifolium repens L.), and lucerne (Medicago sativa L.). Other legume species worth investigating are common bird's-foot trefoil (Lotus corniculatus L.) and hop clover (Medicago lupulina L.). All these legumes species do not grow as tall as yellow melilot but could still become very competitive against miscanthus over the years, because their seeds are expected to spread throughout the miscanthus plantation. Thus, the miscanthus should already be well established when intercropping starts. Consequently, further investigations into the delayed sowing of legumes or other intercropping partners into established miscanthus stands are strongly recommended. Because there is no literature on this topic, new field trials are required to confirm whether this could be a successful method of increasing the ecological performance of miscanthus cultivation.

Author Contributions: Conceptualization, M.v.C. and Y.I.; Data curation, M.v.C.; Formal analysis, M.v.C.; Funding acquisition, I.L.; Investigation, M.v.C.; Methodology, M.v.C.; Project administration, M.v.C. and I.L.; Resources, M.v.C.; Supervision, I.L.; Validation, M.v.C. and Y.I.; Visualization, M.v.C. and Y.I.; Writing一original draft, M.v.C., Y.I., and I.L.; Writing-review and editing, M.v.C.

Funding: This research received funding from the European Union's Horizon 2020 research and innovation programme under grant agreement no. 727698 and the German Federal Ministry of Education and Research (BMBF), project number: 03EK3525A. The article processing charge (APC) was funded by the University of Hohenheim.

Acknowledgments: The authors are thankful to the staff of the Agricultural Experiment Station of the University of Hohenheim for providing technical support for the field trials and to Thomas Ruopp, Andreas Kiesel and Walter Schneider for their assistance with field, laboratory, and preparatory work. The authors are also grateful to Nicole Gaudet for proof-reading the manuscript. The sowing material for yellow melilot (Melilotus officinalis L.) was kindly provided by Saaten-Zeller GmbH \& Co. KG (Eichenbühl-Guggenberg, Germany).

Conflicts of Interest: The authors declare no conflicts of interest. The funders had no role in the design of the study; in the collection, analyses, or interpretation of data; in the writing of the manuscript; or in the decision to publish the results.

\section{References}

1. Scarlat, N.; Dallemand, J.F.; Monforti-Ferrario, F.; Nita, V. The role of biomass and bioenergy in a future bioeconomy: Policies and facts. Environ. Dev. 2015, 15, 3-34. [CrossRef]

2. Staffas, L.; Gustavsson, M.; McCormick, K. Strategies and policies for the bioeconomy and bio-based economy: An analysis of official national approaches. Sustainability 2013, 5, 2751-2769. [CrossRef] 
3. Isbell, F.; Gonzalez, A.; Loreau, M.; Cowles, J.; Díaz, S.; Hector, A.; Mace, G.M.; Wardle, D.A.; O'Connor, M.I.; Duffy, J.E.; et al. Linking the influence and dependence of people on biodiversity across scales. Nature 2017, 546, 65-72. [CrossRef] [PubMed]

4. Scarlat, N. Highlights of the Conference. In Proceedings of the 27th European Biomass Conference \& Exhibition, Lisbon, Portugal, 27-30 May 2019. Available online: http://programme.eubce.com/search.php? close $=$ all (accessed on 31 July 2019).

5. Potts, S.G.; Imperatriz-Fonseca, V.L.; Ngo, H.T.; Biesmeijer, J.C.; Breeze, T.D.; Dicks, L.V.; Garibaldi, L.A.; Hill, R.; Settele, J.; Vanbergen, A.J. Summary for Policymakers of the Assessment Report of the Intergovernmental Science-Policy Platform on Biodiversity and Ecosystem Services on Pollinators, Pollination and Food Production; IPBES: Bonn, Germany, 2016.

6. Hallmann, C.A.; Sorg, M.; Jongejans, E.; Siepel, H.; Hofland, N.; Schwan, H.; Stenmans, W.; Müller, A.; Sumser, H.; Hörren, T. More than 75 percent decline over 27 years in total flying insect biomass in protected areas. PLOS ONE 2017, 12, e0185809. [CrossRef] [PubMed]

7. Habel, J.C.; Segerer, A.; Ulrich, W.; Torchyk, O.; Weisser, W.W.; Schmitt, T. Butterfly community shifts over two centuries. Conserv. Biol. 2016, 30, 754-762. [CrossRef] [PubMed]

8. Tilman, D.; Socolow, R.; Foley, J.A.; Hill, J.; Larson, E.; Lynd, L.; Pacala, S.; Reilly, J.; Searchinger, T.; Somerville, C. Beneficial biofuels-The food, energy, and environment trilemma. Science 2009, 325, 270-271. [CrossRef]

9. Smeets, E.M.W.; Faaij, A.P.C.; Lewandowski, I.M.; Turkenburg, W.C. A bottom-up assessment and review of global bio-energy potentials to 2050. Prog. Energy Combust. Sci. 2007, 33, 56-106. [CrossRef]

10. Philippidis, G.; Bartelings, H.; Helming, J.; M'barek, R.; Smeets, E.; Van Meijl, H. The Good, the Bad and the Uncertain: Bioenergy Use in the European Union. Energies 2018, 11, 2703. [CrossRef]

11. Von Cossel, M.; Lewandowski, I.; Elbersen, B.; Staritsky, I.; Van Eupen, M.; Iqbal, Y.; Mantel, S.; Scordia, D.; Testa, G.; Cosentino, S.L.; et al. Marginal agricultural land low-input systems for biomass production. Energies 2019, 12, 3123. [CrossRef]

12. Norman, D.; Janke, R.; Freyenberg, S.; Schurle, B.; Kok, H. Defining and implementing sustainable agriculture. Kans. Sustain. Agric. Ser 1997, 1, 1-14.

13. Fernando, A.L.; Costa, J.; Barbosa, B.; Monti, A.; Rettenmaier, N. Environmental impact assessment of perennial crops cultivation on marginal soils in the Mediterranean Region. Biomass Bioenergy 2018, 111, 174-186. [CrossRef]

14. Araújo, K.; Mahajan, D.; Kerr, R.; Silva, M.D. Global biofuels at the crossroads: An overview of technical, policy, and investment complexities in the sustainability of biofuel development. Agriculture 2017, 7, 32. [CrossRef]

15. Timsina, J. Can organic sources of nutrients increase crop yields to meet global food demand? Agronomy 2018, 8, 214. [CrossRef]

16. Caslin, B.; Finnan, J.; Easson, L. Miscanthus best practice guidelines. Agric. Food Dev. Auth. Teagasc Agri-Food Biosci. Inst. 2010. Available online: https://www.google.com/url?sa=t\&rct=j\&q=\&esrc=s\&source= web\&cd=1\&cad=rja\&uact=8\&ved=2ahUKEwjn0NrK37nkAhVGx4UKHTSRDn4QFjAAegQIABAC\& url=https $\% 3 \mathrm{~A} \% 2 \mathrm{~F} \% 2 \mathrm{Fwww}$.agriculture.gov.ie\%2Fmedia\%2Fmigration\%2Fruralenvironment $\%$ 2Fenvironment\%2Fbioenergyscheme\%2FMiscanthusBestPracticeManual190913.pdf\&usg= AOvVaw0resIY4jmSLVRNsXS8xsbg (accessed on 31 July 2019).

17. Zegada-Lizarazu, W.; Monti, A. Energy crops in rotation. A review. Biomass Bioenergy 2011, 35, 12-25. [CrossRef]

18. Bybee-Finley, K.A.; Ryan, M.R. Advancing Intercropping Research and Practices in Industrialized Agricultural Landscapes. Agriculture 2018, 8, 80. [CrossRef]

19. Von Cossel, M. Agricultural Diversification of Biogas Crop Cultivation. Ph.D. Thesis, University of Hohenheim, Stuttgart, Germany, 2019.

20. Heaton, E.A.; Schulte, L.A.; Berti, M.; Langeveld, H.; Zegada-Lizarazu, W.; Parrish, D.; Monti, A. Managing a second-generation crop portfolio through sustainable intensification: Examples from the USA and the EU. Biofuels Bioprod. Biorefining 2013, 7, 702-714. [CrossRef]

21. Heaton, E.A.; Dohleman, F.G.; Long, S.P. Meeting US biofuel goals with less land: The potential of Miscanthus. Glob. Chang. Biol. 2008, 14, 2000-2014. [CrossRef] 
22. Monti, A.; Zegada-Lizarazu, W.; Zanetti, F.; Casler, M. Chapter Two-Nitrogen Fertilization Management of Switchgrass, Miscanthus and Giant Reed: A Review. In Advances in Agronomy; Sparks, D.L., Ed.; Academic Press: Cambridge, MA, USA, 2019; Volume 153, pp. 87-119.

23. Nabel, M.; Schrey, S.D.; Poorter, H.; Koller, R.; Jablonowski, N.D. Effects of digestate fertilization on Sida hermaphrodita: Boosting biomass yields on marginal soils by increasing soil fertility. Biomass Bioenergy 2017, 107, 207-213. [CrossRef]

24. Kiesel, A.; Wagner, M.; Lewandowski, I. Environmental performance of miscanthus, switchgrass and maize: Can C4 perennials increase the sustainability of biogas production? Sustainability 2016, 9, 5. [CrossRef]

25. Wagner, M.; Mangold, A.; Lask, J.; Petig, E.; Kiesel, A.; Lewandowski, I. Economic and environmental performance of miscanthus cultivated on marginal land for biogas production. GCB Bioenergy 2019, 11, 34-49. [CrossRef]

26. Heaton, E.; Voigt, T.; Long, S.P. A quantitative review comparing the yields of two candidate C4 perennial biomass crops in relation to nitrogen, temperature and water. Biomass Bioenergy 2004, 27, 21-30. [CrossRef]

27. Alexopoulou, E.; Zanetti, F.; Scordia, D.; Zegada-Lizarazu, W.; Christou, M.; Testa, G.; Cosentino, S.L.; Monti, A. Long-Term Yields of Switchgrass, Giant Reed, and Miscanthus in the Mediterranean Basin. Bioenergy Res. 2015, 8, 1492-1499. [CrossRef]

28. Biala, K.; Terres, J.M.; Pointereau, P.; Paracchini, M.L. Low Input Farming Systems: An opportunity to develop sustainable agriculture. Proc. JRC Summer Univ. Ranco 2007. Available online: https://www. bezpecnostpotravin.cz/userfiles/file/publikace/low-input.pdf (accessed on 31 July 2019). [CrossRef]

29. Lewandowski, I.; Scurlock, J.M.; Lindvall, E.; Christou, M. The development and current status of perennial rhizomatous grasses as energy crops in the US and Europe. Biomass Bioenergy 2003, 25, 335-361. [CrossRef]

30. Lewandowski, I.; Clifton-Brown, J.; Trindade, L.M.; van der Linden, G.C.; Schwarz, K.U.; Müller-Sämann, K.; Anisimov, A.; Chen, C.L.; Dolstra, O.; Donnison, I.S.; et al. Progress on Optimizing Miscanthus Biomass Production for the European Bioeconomy: Results of the EU FP7 Project OPTIMISC. Front. Plant Sci. 2016, 7, 1620. [CrossRef] [PubMed]

31. Winkler, B.; Mangold, A.; Von Cossel, M.; Clifton-Brown, J.; Pogrzeba, M.; Lewandowski, I.; Iqbal, Y.; Kiesel, A. Implementing miscanthus into sustainable farming systems: A review on agronomic practices, capital and labor demand. Renew. Sustain. Energy Rev. under review.

32. Von Cossel, M.; Winkler, B.; Mangold, A.; Lewandowski, I.; Elbersen, B.; Wagner, M.; Magenau, E.; Lask, J.; Staritsky, I.; Van Eupen, M.; et al. Social-ecological implications of miscanthus (Miscanthus $\times$ giganteus Greef et Deuter) cultivation for isobutanol production. Manuscript in preparation.

33. Anderson, E.; Arundale, R.; Maughan, M.; Oladeinde, A.; Wycislo, A.; Voigt, T. Growth and agronomy of Miscanthus x giganteus for biomass production. Biofuels 2011, 2, 71-87. [CrossRef]

34. Iqbal, Y.; Lewandowski, I. Biomass composition and ash melting behaviour of selected miscanthus genotypes in Southern Germany. Fuel 2016, 180, 606-612. [CrossRef]

35. O'Flynn, M.G.; Finnan, J.M.; Curley, E.M.; McDonnell, K.P. Effect of Harvest Timing and Soil Moisture Content on Compaction, Growth and Harvest Yield in a Miscanthus Cropping System. Agriculture 2018, 8, 148. [CrossRef]

36. Cosentino, S.L.; Copani, V.; Scalici, G.; Scordia, D.; Testa, G. Soil erosion mitigation by perennial species under Mediterranean environment. Bioenergy Res. 2015, 8, 1538-1547. [CrossRef]

37. Felten, D.; Emmerling, C. Effects of bioenergy crop cultivation on earthworm communities-A comparative study of perennial (Miscanthus) and annual crops with consideration of graded land-use intensity. Appl. Soil Ecol. 2011, 49, 167-177. [CrossRef]

38. Emmerling, C. Impact of land-use change towards perennial energy crops on earthworm population. Appl. Soil Ecol. 2014, 84, 12-15. [CrossRef]

39. Ruf, T.; Emmerling, C. Impact of premature harvest of Miscanthus x giganteus for biogas production on organic residues, microbial parameters and earthworm community in soil. Appl. Soil Ecol. 2017, 114, 74-81. [CrossRef]

40. Cosentino, S.L.; Testa, G.; Scordia, D.; Alexopoulou, E. Future yields assessment of bioenergy crops in relation to climate change and technological development in Europe. Ital. J. Agron. 2012, 7, 22. [CrossRef]

41. Krasuska, E.; Cadórniga, C.; Tenorio, J.L.; Testa, G.; Scordia, D. Potential land availability for energy crops production in Europe. Biofuels Bioprod. Biorefining 2010, 4, 658-673. [CrossRef] 
42. Tuck, G.; Glendining, M.J.; Smith, P.; House, J.I.; Wattenbach, M. The potential distribution of bioenergy crops in Europe under present and future climate. Biomass Bioenergy 2006, 30, 183-197. [CrossRef]

43. Pachauri, R.K.; Allen, M.R.; Barros, V.R.; Broome, J.; Cramer, W.; Christ, R.; Church, J.A.; Clarke, L.; Dahe, Q.; Dasgupta, P. Climate Change 2014: Synthesis Report. Contribution of Working Groups I, II and III to the Fifth Assessment Report of the Intergovernmental Panel on Climate Change; IPCC: Geneva, Switzerland, 2014.

44. Von Cossel, M.; Wagner, M.; Lask, J.; Magenau, E.; Bauerle, A.; Von Cossel, V.; Warrach-Sagi, K.; Elbersen, B.; Staritsky, I.; Van Eupen, M.; et al. Prospects of Bioenergy Cropping Systems for a more Social-Ecologically Sound Bioeconomy. Agronomy under review.

45. Elmqvist, T.; Folke, C.; Nyström, M.; Peterson, G.; Bengtsson, J.; Walker, B.; Norberg, J. Response diversity, ecosystem change, and resilience. Front. Ecol. Environ. 2003, 1, 488-494. [CrossRef]

46. Folke, C. Resilience: The emergence of a perspective for social-ecological systems analyses. Glob. Environ. Chang. 2006, 16, 253-267. [CrossRef]

47. Xue, S.; Lewandowski, I.; Wang, X.; Yi, Z. Assessment of the production potentials of Miscanthus on marginal land in China. Renew. Sustain. Energy Rev. 2016, 54, 932-943. [CrossRef]

48. Greef, J.M.; Deuter, M. Syntaxonomy of Miscanthus $\times$ giganteus GREEF et DEU. Angew. Bot. 1993, 67, 87-90.

49. Von Cossel, M.; Mangold, A.; Iqbal, Y.; Hartung, J.; Lewandowski, I.; Kiesel, A. How to Generate Yield in the First Year-A Three-Year Experiment on Miscanthus (Miscanthus $\times$ giganteus (Greef et Deuter)) Establishment under Maize (Zea mays L.). Agronomy 2019, 9, 237. [CrossRef]

50. Riffell, S.; Verschuyl, J.; Miller, D.; Wigley, T.B. Potential Biodiversity Response to Intercropping Herbaceous Biomass Crops on Forest Lands. J. For. 2012, 110, 42-47. [CrossRef]

51. Dondini, M.; Hastings, A.; Saiz, G.; Jones, M.B.; Smith, P. The potential of Miscanthus to sequester carbon in soils: Comparing field measurements in Carlow, Ireland to model predictions. GCB Bioenergy 2009, 1, 413-425. [CrossRef]

52. Stewart, J.; Toma, Y.; Fernandez, F.G.; Nishiwaki, A.; Yamada, T.; Bollero, G. The ecology and agronomy of Miscanthus sinensis, a species important to bioenergy crop development, in its native range in Japan: A review. GCB Bioenergy 2009, 1, 126-153. [CrossRef]

53. Semere, T.; Slater, F.M. Ground flora, small mammal and bird species diversity in miscanthus (Miscanthus $\times$ giganteus) and reed canary-grass (Phalaris arundinacea) fields. Biomass Bioenergy 2007, 31, 20-29. [CrossRef]

54. Gansberger, M.; Montgomery, L.F.R.; Liebhard, P. Botanical characteristics, crop management and potential of Silphium perfoliatum L. as a renewable resource for biogas production: A review. Ind. Crops Prod. 2015, 63, 362-372. [CrossRef]

55. Nabel, M.; Barbosa, D.B.P.; Horsch, D.; Jablonowski, N.D. Energy Crop (Sida Hermaphrodita) Fertilization Using Digestate under Marginal Soil Conditions: A Dose-response Experiment. Energy Procedia 2014, 59, 127-133. [CrossRef]

56. Nabel, M.; Temperton, V.M.; Poorter, H.; Lücke, A.; Jablonowski, N.D. Energizing marginal soils-The establishment of the energy crop Sida hermaphrodita as dependent on digestate fertilization, NPK, and legume intercropping. Biomass Bioenergy 2016, 87, 9-16. [CrossRef]

57. Jablonowski, N.D.; Kollmann, T.; Nabel, M.; Damm, T.; Klose, H.; Müller, M.; Bläsing, M.; Seebold, S.; Krafft, S.; Kuperjans, I.; et al. Valorization of Sida (Sida hermaphrodita) biomass for multiple energy purposes. GCB Bioenergy 2017, 9, 202-214. [CrossRef]

58. Von Cossel, M.; Lewandowski, I. Perennial wild plant mixtures for biomass production: Impact of species composition dynamics on yield performance over a five-year cultivation period in southwest Germany. Eur. J. Agron. 2016, 79, 74-89. [CrossRef]

59. Von Cossel, M.; Steberl, K.; Hartung, J.; Agra Pereira, L.; Kiesel, A.; Lewandowski, I. Methane yield and species diversity dynamics of perennial wild plant mixtures established alone, under cover crop maize (Zea mays L.) and after spring barley (Hordeum vulgare L.). GCB Bioenergy 2019, in press. Available online: https://onlinelibrary.wiley.com/doi/full/10.1111/gcbb.12640 (accessed on 5 September 2019). [CrossRef]

60. Kohli, L.; Daniel, O.; Schönholzer, F.; Hahn, D.; Zeyer, J. Miscanthus sinensis and wild flowers as food resources of Lumbricus terrestris L. Appl. Soil Ecol. 1999, 11, 189-197. [CrossRef]

61. Isbell, F.; Adler, P.R.; Eisenhauer, N.; Fornara, D.; Kimmel, K.; Kremen, C.; Letourneau, D.K.; Liebman, M.; Polley, H.W.; Quijas, S. Benefits of increasing plant diversity in sustainable agroecosystems. J. Ecol. 2017, 105, 871-879. [CrossRef] 
62. Holzschuh, A.; Dainese, M.; González-Varo, J.P.; Mudri-Stojnić, S.; Riedinger, V.; Rundlöf, M.; Scheper, J.; Wickens, J.B.; Wickens, V.J.; Bommarco, R.; et al. Mass-flowering crops dilute pollinator abundance in agricultural landscapes across Europe. Ecol. Lett. 2016, 19, 1228-1236. [CrossRef] [PubMed]

63. Potts, S.G.; Woodcock, B.A.; Roberts, S.P.M.; Tscheulin, T.; Pilgrim, E.S.; Brown, V.K.; Tallowin, J.R. Enhancing pollinator biodiversity in intensive grasslands. J. Appl. Ecol. 2009, 46, 369-379. [CrossRef]

64. Emmerling, C.; Pude, R. Introducing Miscanthus to the greening measures of the EU Common Agricultural Policy. GCB Bioenergy 2017, 9, 274-279. [CrossRef]

65. European Commission. Commission Delegated Regulation; Report from the Commission to the European Parliament and the Council; European Commission: Brussels, Belgium, 2018. Available online: https: //eur-lex.europa.eu/legal-content/EN/TXT/?qid=1490786763554\&uri=COM:2017:152:FIN (accessed on 31 July 2019).

66. GRACE. GRowing Advanced Industrial Crops on Marginal Lands for BiorEfineries. 2019. Available online: https://www.grace-bbi.eu/project/ (accessed on 14 June 2019).

67. Frick, M.; Pfender, G. AG Wildpflanzen-Biogas Kißlegg. In Biogas aus Wildpflanzen-Chancen und Herausforderungen Mehrjähriger Wildpflanzenmischungen zur Biogasnutzung aus Sicht der Forschung und der Praxis; University of Hohenheim: Stuttgart, Germany, 2019. Available online: https://baden-wuerttemberg. nabu.de/natur-und-landschaft/landwirtschaft/biogas/index.html (accessed on 31 July 2019).

68. Kuhn, W.; Zeller, J.; Bretschneider-Herrmann, N.; Drenckhahn, K. Energy from Wild Plants_Practical Tips for the Cultivation of Wild Plants to Create Biomass for Biogas Generation Plants; Jagdverband e.V.: Berlin, Germany, 2014; Volume 1, ISBN 978-3-936802-16-0. Available online: lebensraum-brache.de/wp-content/uploads/2014/ 09/NLF_Praxisratgeber_Englisch_140905.pdf (accessed on 31 July 2019).

69. Xiong, G.R.; Zheng, J.F.; Wu, Y.X.; He, Y.Q. A new disease, clubroot of Isatis tinctoria L. J. Agric. Catastro 2012, $2,3-4$.

70. Chai, A.L.; Xie, X.W.; Shi, Y.X.; Li, B.J. Research status of clubroot (Plasmodiophora brassicae) on cruciferous crops in China. Can. J. Plant Pathol. 2014, 36, 142-153. [CrossRef]

71. Nabel, M.; Schrey, S.D.; Temperton, V.M.; Harrison, L.; Jablonowski, N.D. Legume Intercropping with the Bioenergy Crop Sida hermaphrodita on Marginal Soil. Front. Plant Sci. 2018, 9, 905. [CrossRef]

72. Xue, S.; Kalinina, O.; Lewandowski, I. Present and future options for Miscanthus propagation and establishment. Renew. Sustain. Energy Rev. 2015, 49, 1233-1246. [CrossRef]

73. Iqbal, Y.; Gauder, M.; Claupein, W.; Graeff-Hönninger, S.; Lewandowski, I. Yield and quality development comparison between miscanthus and switchgrass over a period of 10 years. Energy 2015, 89, 268-276. [CrossRef]

(C) 2019 by the authors. Licensee MDPI, Basel, Switzerland. This article is an open access article distributed under the terms and conditions of the Creative Commons Attribution (CC BY) license (http://creativecommons.org/licenses/by/4.0/). 